REBEKAH GERRY

\title{
CIVIL DEFENCE EMERGENCY MANAGEMENT ACT 2002: AMBIGUITIES AND THE PRIVATE SECTOR
}

Submitted for the LLB (Honours) Degree

Faculty of Law

TE Whare Wánanga o te úpoko o te tKa a mãui

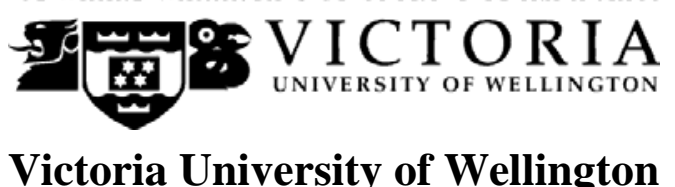

2014 


\begin{abstract}
:
This papers reviews the Civil Defence Emergency Management Act 2002 and the regime it establishes. Although this regime works well most of the time, there are four key areas that need addressing. Incidents such as the 2013 Seddon earthquakes have highlighted the uncertainty around the definitional threshold of an emergency and requirements for a state of emergency. Further, the powers of emergency management actors are not clear. The paper also explores the actual and potential obligations and liability of the private sector. Five recommendations are ultimately made to address these issues.
\end{abstract}

\title{
Keywords:
}

Civil Defence Emergency Management Act 2002;

Private Sector;

Emergency Powers;

\section{Table of contents:}

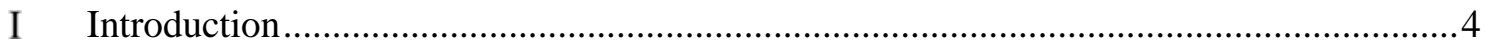

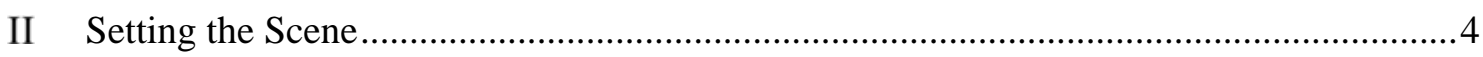

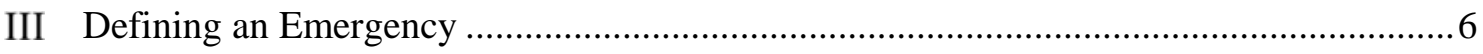

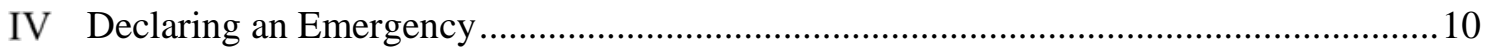

V Powers of Emergency Management Actors............................................................14

A Without a State of Emergency ….......................................................................... 14

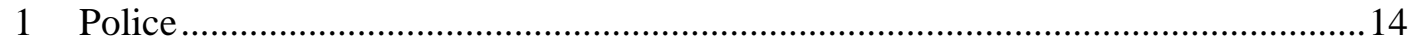

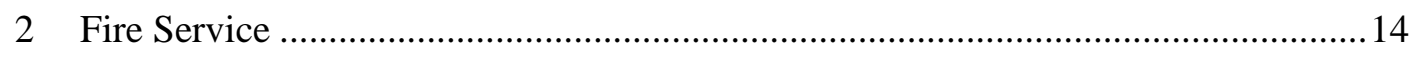

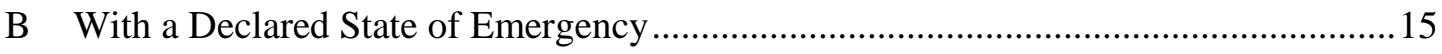

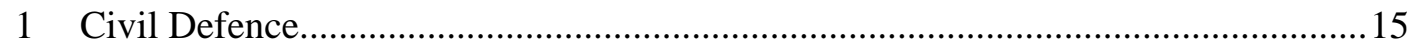

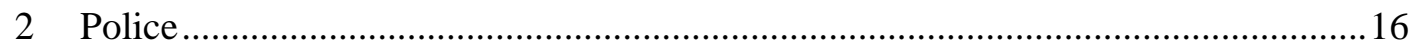

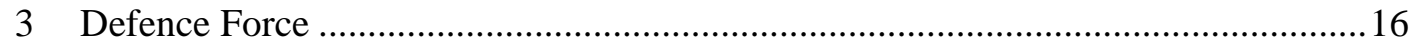

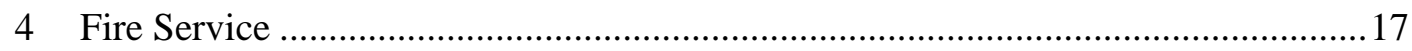

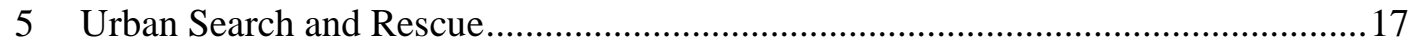

C Coordinated Incident Management Strategy ..............................................................18

VI Obligations and Liabilities of the Private Sector ......................................................19 


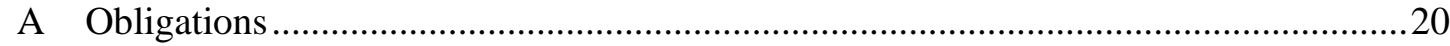

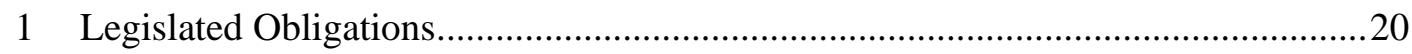

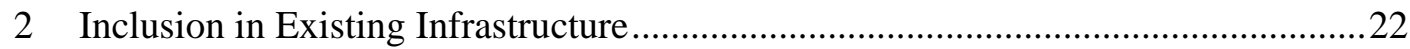

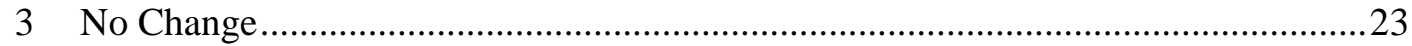

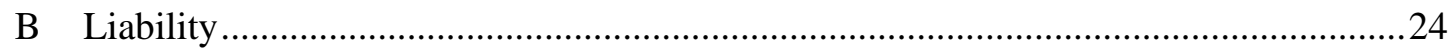

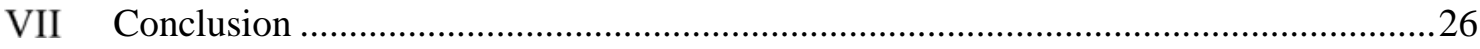

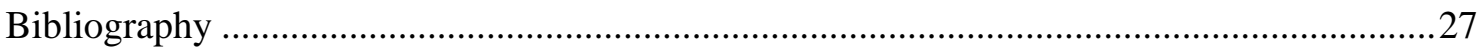




\section{Introduction}

The Civil Defence Emergency Management Act 2002 (CDEM Act), and related instruments, work to create effective preparations for and responses to emergency situations in New Zealand. The CDEM Act defines what an emergency is, ${ }^{1}$ and outlines the ability to declare states of emergency. ${ }^{2}$ Following such declarations, a variety of statutory powers are available to various actors, including the Police, Fire Service, Defence Force and Civil Defence personnel. ${ }^{3}$ Thus, despite the high likelihood and prevalence of natural disasters in New Zealand, there is a low mortality rate and a high level of government response. The issue in the regime is whether the public's, and the private sector's, expectations align with what actions Civil Defence and other actors take in reality. The Seddon earthquakes in 2013 caused confusion, particularly in the private sector, around the Civil Defence response to smaller-scale incidents. This paper seeks to clarify some of the issues in the CDEM Act regarding such incidents; whether they are classed as emergencies, whether states of emergencies can be declared, and the powers of emergency service actors. Finally, this paper explores whether the private sector should be more involved in Civil Defence, either through dialogue or statutory obligations.

\section{Setting the Scene}

Civil defence emergency management inhabits an integral place in New Zealand society. New Zealand's unique geographical position between two tectonic plates, and the temperate climate, place it at a constant risk of natural disaster. ${ }^{4}$ As such, the likelihood of an emergency situation in New Zealand, and in particular Wellington, is high. Emergency situations in the Wellington region will also be exacerbated due to vulnerable transport links, the risk of multiple hazards (e.g. earthquake causing tsunami and landslides), a high number of commuters causing varying population densities and severe income disparities meaning lower socio-economic groupings are less likely to be prepared for emergencies. ${ }^{5}$ The country, and individual regions, need to have competent plans of action to decrease damage and the likelihood of panic and confusion during any emergency situation.

\footnotetext{
${ }^{1}$ Section 4, definition of 'emergency'.

${ }^{2}$ Part 4.

${ }^{3}$ Part 5.

${ }^{4}$ Wellington Region Civil Defence Emergency Management Group Plan 2013-2018 (1 July 2013) at 8.

${ }^{5}$ Ibid.
} 
Clear knowledge of actors' relevant powers and responsibilities will allow better responses and emergency management. Finally there are the policy considerations of balancing risk management and safety in emergency situations against the need to continue to foster economic and social activities.

There is ambiguity regarding the civil defence powers and responsibilities (if any) of private sector employers. This was highlighted by the recent series of earthquakes which hit Seddon, 55 kilometres south of Wellington, in July 2013. This caused wide-spread damage across the region and rattled the nerves of the capital's inhabitants. ${ }^{6}$ Victoria University of Wellington suffered damage, particularly to its Law School, housed in the historic government buildings. ${ }^{7}$ Although this earthquake was of a similar magnitude to the hugely damaging 2011 Christchurch earthquake, it did not result in a declaration of a state of emergency. The reasons for this will be examined below, but key considerations were that the coordinative and special powers of the CDEM Act were not necessary to respond to the Wellington earthquakes. Without such a declaration, it remained ambiguous as to which powers were legally authorised.

These circumstances highlighted some grey areas that exist in our civil defence emergency management regime. This paper seeks to explore and clarify these grey areas, as well as comment upon possible changes which would provide further support to actors involved in any emergency, to the private sector and to the general public.

The primary concerns for this paper are:

1. At what threshold does an incident become an emergency?

2. How is the decision to declare a state of emergency made in practice?

3. What powers are available to emergency responders both with and without a declaration of a state of national or local emergency?

4. Should the private sector be further involved in civil defence emergency management, and if so, what obligations and liabilities would they have?

\footnotetext{
${ }^{6}$ Rebecca Quilliam “Wellington earthquake: 35 buildings damaged in CBD” The New Zealand Herald (online ed, Auckland, 2 July 2013).

7 Jo Moir “Lecturers to cut law students some slack” The Dominion Post (online ed, Wellington, 24 July 2013).
} 
These issues must be clarified, as confusion and uncertainty about what is the correct action could cause an illegal act or omission. This could lead to, or exacerbate, adverse outcomes of an emergency incident. Such ambiguity opens up emergency management actors and others to legal liability. If emergency services or Civil Defence acted with powers they thought were available to them, but which were in fact not available, then their actions could be judicially reviewable. Protection against individual liability for loss or damage under the CDEM Act only extends to the use of authorised powers. Any ultra vires action which results in damage to people or property could be open for suit.

The chief piece of legislation in this area is the Civil Defence Emergency Management Act 2002. This replaced and repealed the earlier act of $1983 .{ }^{8}$ The CDEM Act comprehensively sets out definitions, powers and limitations for civil defence emergency management. Civil defence emergency management involves a coordinated response to extraordinary circumstances. There is a requirement that each region have a Civil Defence Emergency Management Group (CDEM Group). ${ }^{9}$ These groups allow coordination of planning and responses to civil defence emergency between key stakeholders, such as local authorities, Police, Fire Service, ambulance providers, urban search and rescue, Civil Defence personnel and the Defence Force. Each CDEM Group must submit an emergency management plan. ${ }^{10}$ The Wellington Region Emergency Management team is based in Thorndon, Wellington. It is one of six Emergency Operations Centres in the region. ${ }^{11}$ CDEM Regional Groups are monitored by the Director of Civil Defence, who reports to the Minister of Civil Defence and Emergency

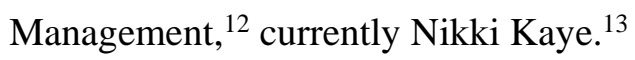

\section{Defining an Emergency}

All incidents, from daily occurrences to what we would colloquially call 'emergencies', through to declared states of emergencies, fall somewhere upon the spectrum below.

\footnotetext{
${ }^{8}$ Civil Defence Emergency Management Act, s 3.

${ }^{9}$ Section 12.

10 Section 17.

${ }^{11}$ Interview with Bruce Pepperell, Wellington Region Emergency Management Regional Manager (Rebekah Gerry, 31 July 2014).

12 Civil Defence Emergency Management Act, s 8.

13 Beehive "Ministerial List for Announcement” (press release, 22 January 2013).
} 


\section{1) Daily Occurrence}

\section{2) Out of the ordinary events - (colloquial emergencies)}

\section{3) Events meeting the CDEM}

Act definition of emergency

\section{4) Local state of emergency}

\section{5) National state of emergency}

Figure 1 - Incident Spectrum

The third category covers incidents that meet the definition of emergency given by the CDEM Act in s 4 as: ${ }^{14}$

a situation that -

(a) is the result of any happening, whether natural or otherwise, including, without limitation, any explosion, earthquake, eruption, tsunami, land movement, flood, storm, tornado, cyclone, serious fire, leakage or spillage of any dangerous gas or substance, technological failure, infestation, plague, epidemic, failure of or disruption to an emergency service or a lifeline utility, or actual or imminent attack or warlike act; and

(b) causes or may cause loss of life or injury or illness or distress or in any way endangers the safety of the public or property in New Zealand or any part of New Zealand; and

(c) cannot be dealt with by emergency services, or otherwise requires a significant and coordinated response under this Act.

As can be seen, this is a three-part test. All elements must be met before it can be classed as an emergency and before a state of emergency can be declared. Multiple related pieces of legislation were amended under the CDEM Act, in an attempt to provide standardisation across New Zealand agencies. ${ }^{15}$

Despite this, the Policing Act 2008, the Fire Service Act 1975 and the Defence Act 1990 do not seem to align with this definition. In the first of these, 'emergency' itself is never specifically defined, so it is difficult to state whether it is used in a way consistent with

\footnotetext{
${ }^{14}$ Civil Defence Emergency Management Act, s 4, definition of “emergency”.

${ }^{15}$ Section 117.
} 
the Civil Defence definition or with colloquial definitions. In the Fire Service Act, although 'emergency' is defined in the same way as in the CDEM Act, it also includes specific reference to hazardous substance emergencies. ${ }^{16}$ Moreover, references to emergency throughout the Fire Service Act also do seem to include incidents of a lower threshold (a more colloquial usage of the word emergency). The Defence Act also contains no definition of emergency. Instead, s 9, which authorises Defence Force assistance to the civil power, refers to situations where "one or more persons are threatening to kill or seriously injure”, rather than civil defence emergencies. ${ }^{17}$ The discrepancies between these Acts in terms of definitions is concerning. Miscommunication is undesirable, given the life and death emergency situations in which these actors often find themselves.

There are two suggested ways to resolve this issue, the first being to bring these pieces of legislation into line with the CDEM Act definition of an emergency. It would clarify the definition and create stronger communication between all actors. However, it is important for the Police and the Fire Service to have a colloquial definition of what an emergency is, rather than the civil defence definition. Their statutory roles see them frequently deal with events such as car accidents and house fires, as well as more serious incidents like severe storms, flooding and minor earthquakes. It is possible that none of these would meet the CDEM Act definition of emergency. Defining emergencies in this limited civil defence way could narrow the scope of Police and Fire Service actions, dangerously excluding a series of situations which are in fact dealt with by them every day.

The alternative solution is to remove paragraph (c) from the definition of emergency in the CDEM Act. This would create a lower definition of emergency, including category 2) on the incident spectrum diagram above as emergencies. It would remove problems of consistency between the emergency services’ Acts which do not fully comply. This would reduce the likelihood of miscommunication between these actors.

Currently, paragraph (c) creates a subjective element which means that similar incidents may or may not be classed as emergencies, dependent on the capacity of local emergency

${ }^{16}$ Fire Service Act 1975, s 2, definition of “emergency”.

${ }_{17}$ Defence Act 1990, s 9(4). 
services. This makes it harder for national planning, as it is unclear whether a region had fewer emergency situations, or if it was simply better equipped. Objective understandings of what is and is not an emergency will allow for better records, and therefore more effective planning and funding. Whilst this subjectivity provides flexibility as to whether or not Civil Defence will become involved, this decision will happen regardless.

In addition, a lower threshold for defining an emergency would better reflect ongoing practice and understandings. Incidents such as serious flooding, minor earthquakes or severe storms are out of the ordinary, and currently already dealt with by emergency services and Civil Defence. In practice, despite the fact that smaller-scale incidents sometimes do not reach the CDEM Act's definition of emergency, Civil Defence is still involved. They often provide welfare and coordination support to other emergency services through Emergency Operations Centres. ${ }^{18}$ Removal of this element in the definition of 'emergency' under the CDEM Act would properly reflect this. Also, in these situations the public often has an expectation that it is Civil Defence who is handling them. This is partially due to the colloquial definition of emergency, which sits at this lower threshold. Aligning the legal and layman definitions is important, as it will often be a situation in which communication with the public is key in responding to the particular incident.

Smaller-scale coordinative responses that do not rely on the special powers of the CDEM Act are often still needed, regardless of the capacity of emergency powers. Currently, it seems that Civil Defence operates in these situations, despite the fact they would not meet the definitional requirements of an emergency under paragraph (c). Therefore, it seems that common sense generally prevails in the practical actions of emergency management actors.

As outlined above, the removal of paragraph (c) from the definition of emergency would reflect ongoing practice, align the definition with the layman's understanding and reduce the potential negatives of subjectivity. If this were to happen, however, those limitations should be carried over as a necessary threshold before the declaration of a state of emergency can happen. This requirement limits the availability of special emergency

\footnotetext{
${ }^{18}$ Above, n 11.
} 
powers, and prevents ad hoc declarations of states of emergency. Such declarations can often have an impact upon public confidence, and local or national business and investment reputations. ${ }^{19}$ Excessive use of declarations could also result in a 'boy who cried wolf' scenario. Requiring the higher threshold of paragraph (c) - that the incident is beyond the capabilities of local emergency services or requires the coordinating powers of the CDEM Act - before declaring a state of emergency will prevent these negative outcomes.

\section{Declaring an Emergency}

Under the CDEM Act, a declaration of a state of local or national emergency may be made, if an emergency has occurred or may occur. ${ }^{20}$ This must be done by the authorised person under pt 4 of the CDEM Act, either the mayor or Minister, by virtue of their positions as the people's elected representatives. ${ }^{21}$ National states of emergency can be declared where: ${ }^{22}$

the emergency is, or is likely to be, of such extent, magnitude, or severity that the civil defence emergency management necessary or desirable in respect of it is, or is likely to be, beyond the resources of the Civil Defence Emergency Management Groups whose areas may be affected by the emergency.

The first national state of emergency occurred on 23 February 2011, in the aftermath of the 6.3-magnitude Christchurch earthquake. That state of emergency lasted around 10 weeks. ${ }^{23}$ Once declared, a state of emergency is usually terminated automatically after 7 days, ${ }^{24}$ but there is the ability to extend it. ${ }^{25}$

Under the CDEM Act, whether or not to declare a state of emergency is entirely up to the authorised decision-maker. For states of local emergency, the only condition is that an emergency has occurred or may occur. ${ }^{26}$ For a national state of emergency, the requirements are as quoted above. In reality, regulations and guidelines, such as the

\footnotetext{
19 Ibid.

${ }^{20}$ Section 68(1).

21 Sections 66, 68-69.

22 Section 66(1)(b).

${ }^{23}$ Beehive "State of national emergency expires” (press release, 2 May 2011).

${ }^{24}$ Civil Defence Emergency Management Act, s 70(3).

25 Section 71.

${ }^{26}$ Section 68(1)
} 
National Plan for Civil Defence Emergency Management, provide further support for this practical assessment of whether a declaration of a state of emergency is necessary or desired. ${ }^{27}$ The Director's Guidelines for the CDEM Sector states explicitly: ${ }^{28}$

The fact that an emergency exists does not necessarily warrant a declaration of a state of emergency. The primary consideration for declaring a state of emergency is whether the special powers provided by the Act under a state of emergency are required or deemed to be required to best manage the emergency.

As well as ensuring the situation meets the three-part definition under the CDEM Act, these guidelines require the decision-maker to consider a range of factors before declaring a state of emergency. Outlined in Annex 2, they include: what evacuation requirements are necessary, the status of lifeline and social utilities, whether or not the emergency powers under pt 5 of the CDEM Act are needed, and the status of emergency services. ${ }^{29}$ Timing is also a consideration; earlier declarations allow more preparation and enable workplaces and schools to shut, ensuring fewer people will be stranded. ${ }^{30}$ Day-time declarations also give responders a chance before darkness impairs vision. Finally, it must be possible to immediately notify emergency services, the media and the public, not just Civil Defence itself. The overall concern is whether special emergency powers would add value to the management of the emergency. ${ }^{31}$

This process works well in practice. It is a statutory requirement to have representatives from each of the emergency services on the CDEM Groups. ${ }^{32}$ Consequently, there is a strong working relationship between all emergency services, the city council and the Civil Defence. ${ }^{33}$ Emergency services will suggest to the CDEM Group if they feel a declared state of emergency would be beneficial. ${ }^{34}$ There have been incidents where recommendations to declare a state of emergency from an emergency service actor were not heeded until much later, but outright refusal is uncommon. ${ }^{35}$ The process also works with a healthy dose of Kiwi pragmatism, where each actor knows and understands the

${ }^{27}$ National Civil Defence Emergency Management Plan Order 2005.

${ }^{28}$ Ministry of Civil Defence Director's Guidelines for the CDEM Sector (DGL13/12, March 2012) at 6.

${ }^{29}$ Ibid, at Annex 2.

${ }^{30}$ Ibid, at 9.

${ }^{31}$ Ibid.

${ }^{32}$ Civil Defence Emergency Management Act, s 20(1).

33 Above, $\mathrm{n} 11$.

${ }^{34}$ Interview with Stu Rooney, National Operations Officer of NZ Fire Service (Rebekah Gerry, 1 August 2014).

${ }^{35}$ Ibid. 
limits of their own capabilities and when to suggest that a civil defence emergency should be declared.

Examples of this decision-making process were given by the Wellington Region Emergency Management Office (WREMO) Regional Manager Bruce Pepperell. ${ }^{36}$ Following the July and August 2013 Seddon earthquakes, it was decided not to declare a local state of emergency. The first two elements for the definition of an emergency were met as an earthquake had occurred that caused damage to people and property in New Zealand. However, it was decided that emergency services could handle the situation, and the special powers granted under the CDEM Act were not necessary for recovery or damage minimisation. ${ }^{37}$ The decision was made by the mayor as the authorised person under the CDEM Act, following a consultative discussion with emergency service stakeholders. Residents were still strongly advised against coming into work on the Monday morning. ${ }^{38}$ Despite having no formal powers to exclude people from the city centre, this announcement was sufficient to deter workers. Emergency services could and did manage the damage caused by those earthquakes, with the assistance of the Emergency Operations Centre run by Civil Defence.

Ultimately, the decision of whether or not to declare is tied up in the assessment of whether or not special emergency powers are required. The ability to receive powers from other sources of legislation, such as the Fire Service Act 1975 or the Building Act 2004, can sometimes lead to a reluctance to declare a state of emergency. Mr Pepperell gave an example of this pragmatism in practice. Following a significant earthquake in August 2013, an external lift shaft attached to the James Smith’s parking building had come loose and needed to be safely dismantled. ${ }^{39}$ Accordingly, residents from neighbouring buildings needed to be evacuated. They were reluctant to go. Instead of using CDEM Act powers, WREMO decided to use powers given to the City Council under the Building Act 2004 to require their eviction. ${ }^{40}$ The ability to use these powers contributed to a reluctance to declare a state of emergency, as special powers were not necessary.

\footnotetext{
${ }^{36}$ Above, n 11.

${ }^{37}$ Ibid.

${ }^{38}$ Ibid.

39 "Work to begin to demolish lift shaft following Wellington quake” One News (online ed, New Zealand, 16 August 2013).

40 Above, n 11.
} 
The flexibility in this decision-making allows the CDEM Group to bide their time and assess a situation before making a decision on whether or not to declare. As mentioned above, while it is always open to a CDEM Group to declare a state of emergency later, earlier declarations allow better preparation. This must be weighed against the potential negative consequences of unnecessary declarations. Coordinating incidents that are easily managed by emergency services would strain relationships between actors and waste public money.

Not declaring signals confidence in emergency service actors to do their job, and that the public should trust them to do so. Further, declaring a state of emergency can have negative impacts upon the region's investment, business, tourism and public morale, and should not be done lightly. Smaller city councils are sometimes concerned about the cost that declaring a state of emergency may have. ${ }^{41}$ These factors need to be weighed up against any potential benefits, such as special emergency powers, or clarification of the situation for the public.

Decisions about declarations are sometimes criticised for not being transparent. Except for the role of the mayor as the representative official, there is no contribution by the private sector or wider community to CDEM Groups. Often following an emergency, the public and the private sector may assume a declaration of emergency will follow. When it does not, there is no requirement that any statement needs to be made by the CDEM Group, stating that a declaration has not occurred, and the reasons why. It could be possible to legislate that the reasons for a declaration or non-declaration must be made public. To do so would give clarity and reassurance to the public that Civil Defence is acting, and the region has the capacity to handle this emergency without the need for special powers. These benefits would outweigh any potential criticism that could be directed at CDEM Groups. In practice, however, such communication may be difficult, given that communication channels may be down.

${ }^{41}$ Above, n 34. 


\section{Powers of Emergency Management Actors}

\section{A Without a State of Emergency}

As the decision to declare a state of emergency is tied to the necessity of special emergency powers, it is necessary to look at these as well as the everyday powers of emergency management actors. The most significant actors whose everyday powers would be used are the Police and Fire Service.

\section{Police}

The New Zealand Police Force has relatively wide powers under its normal empowering legislation, the Policing Act 2008. This Act outlines the structure and role of the New Zealand Police Force. Importantly, section 9 outlines the functions of the Police as including, in paragraph (h), 'emergency management' ${ }^{42}$ The role of Police in emergency management is not further discussed in this Act. Some special powers given to Civil Defence by the CDEM Act are already part of Police powers. For example, even without a state of emergency, constables have the power to close roads to traffic if there is reasonable cause to believe that "danger to a member of the public exists or may reasonably be expected at or near that place”. ${ }^{43}$ This provision would allow the Police to close roads during non-declared emergencies and other incidents which do not meet the definition of emergency.

\section{Fire Service}

The Fire Service Act 1975 establishes the Fire Service and outlines their role within the community. For the purposes of this paper, which is largely focussed on urban responses, the Rural Fire Authority will not be considered. Under the Fire Service Act 1975, the Fire Service is granted a wide range of powers to deal with fires and other emergencies. Section 28 details these powers extensively. It states that in emergencies other than those involving a fire or hazardous substances, if it is considered that the fire brigade could render assistance, they "shall take whatever action is necessary to save lives and property in danger”. ${ }^{44}$ The wide ambit of these powers means that during a small earthquake or

\footnotetext{
${ }^{42}$ Section 9(h).

${ }^{43}$ Policing Act, 25(1)(b).

${ }^{44}$ Fire Service Act, 28(3)
} 
minor natural disaster, the Fire Service is expected to deal with call-outs as they would on a usual day.

\section{B With a Declared State of Emergency}

Once a state of emergency is declared, special emergency powers are authorised by pt 5 of the CDEM Act. As Matthew McKillop states: ${ }^{45}$

The necessity for emergency powers... lies partially in the greater need for haste during an emergency situation, and otherwise in the need for clearly delineated powers and sanctions to compel compliance with police requests.

The existence of these powers under the CDEM Act allows emergency response actors, particularly the Police and Civil Defence, to quickly react, without the need for particular legislative endorsement. Not declaring a state of emergency indicates that the CDEM Group believes emergency services can manage the situation using their everyday powers.

\section{Civil Defence}

Almost all of the special powers available during a state of emergency are given to CDEM Groups. They are granted the powers to clear roads, remove or dispose of dangerous structures, rescue endangered people, provide first aid, emergency food clothing and shelter, prohibit and regulate travel in an area, provide information and take emergency measures to dispose of dead people and animals. ${ }^{46}$ In addition, any works carried out to mitigate damage are exempt from normal resource consent procedure. ${ }^{47}$ CDEM Groups can also evacuate or break into premises if deemed 'necessary' ${ }^{48}$ This term appears to have a wholly subjective meaning. This subjectivity is positive in allowing for flexibility depending on the individual factors of an incident. However, it can lead to different interpretations, which raises the possibility that a retrospective look would find the action was not necessary.

\footnotetext{
${ }^{45}$ Matthew McKillop "Emergency Powers of the New Zealand Government: Sources, Limitations, and the Canterbury

Earthquake" (Otago University Honours Dissertation, October 2010) at 3.

${ }^{46}$ Civil Defence Emergency Management Act, s 85(1).

${ }^{47}$ Resource Management Act 1991, s 330B(1).

${ }^{48}$ Civil Defence Emergency Management Act, ss 86-87.
} 
There are also national and local plans that will be put into action once a state of emergency has been declared. Director's Guidelines by Civil Defence provide supplemental information to those with statutory roles or powers. All actors follow procedures under the Coordinated Incident Management Strategy (CIMS), explained further below.

\section{Police}

Police gain increased powers under CDEM Act. These powers include the ability to require information that is reasonably necessary for civil defence emergency management, and the ability to seek a warrant to obtain such information from a property, if there is an imminent threat of emergency (except a dwelling-house). ${ }^{49}$

Additional powers granted to Police officers and those in Civil Defence include the ability to order the evacuation of a place, or the exclusion from a place, and to close roads or public places, remove vehicles and to give directions. ${ }^{50}$ Some specific powers allow delegation from an authorised person to a member of the public. ${ }^{51}$ This is most often delegated to other emergency service workers, such as Fire Service and urban search and rescue (USAR), as well as volunteer rescue teams. The Police can direct people to stop activity which may cause or substantially contribute to an emergency ${ }^{52}$, and it is an offence if that activity is not stopped. ${ }^{53}$ They also have the ability to direct members of the public to take action to prevent or limit the extent of the emergency. ${ }^{54}$ However, there is no liability if members of the public do not do so.

\section{Defence Force}

The Defence Act 1990 gives the Governor-General the power to raise and maintain armed forces for multiple purposes, including "the provision of assistance to the civil power either in New Zealand or elsewhere in time of emergency", 55 and "the provision of any public service”. ${ }^{56}$ Once a state of emergency is declared, the Governor-General

\footnotetext{
${ }^{49}$ Civil Defence Emergency Management Act, s 78.

${ }^{50}$ Sections 86-89.

${ }^{51}$ Sections 76, 78, 86-92.

${ }^{52}$ Section 91(a).

53 Section 102.

${ }^{54}$ Section 91(b).

${ }^{55}$ Section 5(e).

${ }^{56}$ Section 5(f).
} 
may, by proclamation, declare either the territorial or reserve forces to be liable for continuous service for the duration of the state of emergency. ${ }^{57}$ If the Defence Force is called to assist the civil power, the House of Representatives must be informed as soon as possible ${ }^{58}$, and any authority given to the armed forces will lapse after 14 days unless extended. 59

It is clear that the New Zealand Defence Force is an auxiliary and support force to existing emergency services. This is to separate the role of the military and the Police, but there is also recognition of the need for support during times of emergency. It should be noted that this point is also emphasised by s $9(2)$, which states the military may never be used during industrial dispute situations. ${ }^{60}$

\section{Fire Service}

During a declared state of emergency, Fire Service gains no additional powers under the CDEM Act, except if delegated to it by the Police or Civil Defence. Under the National Civil Defence Emergency Management Plan, the Fire Service is the chief emergency management actor for any fire or hazardous substance emergency, as well as the main liaison with USAR, a critical stakeholder in emergency response management. ${ }^{61}$ Fire Service internal rules require the approval of the National Fire Commander before any USAR deployment occurs. ${ }^{62}$

\section{Urban Search and Rescue}

Urban Search and Rescue has no formal mandate under New Zealand legislation, despite the fact it plays a key role in many emergency situations both domestically and internationally. Emergency actors on the ground may ask for assistance. The level of response varies from sending a few skills-specific people, to a full-blown response team of around 70. Following the July 2013 earthquake, engineers were sent to help the Wellington City Council evaluate building standards. ${ }^{63}$

\footnotetext{
${ }^{57}$ Defence Act, ss 39-40.

${ }^{58}$ Section $9(7)$.

${ }^{59}$ Section $9(8)$.

${ }^{60}$ Section $9(2)$.

${ }^{61}$ Above, n 27, cl 26(1).

${ }^{62}$ Above, $\mathrm{n} 34$.

63 "New Zealand Fire Service USAR team helping out in Wellington" (22 July 2013) New Zealand Fire Service $<$ www.fire.org.nz>.
} 
It is closely affiliated with the Fire Service. However, it is not mentioned in the Fire Service Act 1975, largely because it has been established relatively recently. Around $90 \%$ of the USAR members are also Fire Service members, the rest mostly being structural engineers. ${ }^{64}$ The Fire Service has sufficient fire-fighting capability to allow these USAR members to take on that role following an emergency. ${ }^{65}$

New Zealand still desperately needs to include USAR into its emergency management planning. Although it is mentioned in the National CDEM Plan, there is no controlling legislation and it exists in a legal limbo as a semi-autonomous body affiliated with the Fire Service ${ }^{66}$ Currently the only controls and empowerment exist through authorisation by the Police or a CDEM Group under the emergency powers of the CDEM Act or the internal rules of the Fire Service. Legislating or at least regulating the authority and powers of USAR would be a huge step in clarifying the role and responsibility of this emergency response actor. Given the increasing importance of its role, codifying its responsibilities in relation to other emergency management actors would aid communication and delegation of tasks in an emergency situation.

\section{Coordinated Incident Management Strategy}

In New Zealand, all incidents are dealt with under the Coordinated Incident Management Strategy (CIMS). ${ }^{67}$ This outlines the process of first response and subsequent authority. The protocol is that control and authority of an incident goes to whichever agency arrives on the scene first. This is often the Fire Service or Police. If the incident requires coordination of more than one agency, the lead agency will be the one which is most appropriate, and authority will be passed to them from the first responder once they have been adequately briefed on the situation. The 'appropriate' agency is often a matter of common sense, with Police handling law and order incidents, Fire Service covering fires and other hazardous substances, Civil Defence in charge of natural disasters and welfare issues, and Ministry of Health being the lead agency for disease outbreaks.

\footnotetext{
${ }^{64}$ Above, n 34.

65 Ibid.

${ }^{66}$ Above, $\mathrm{n} 34$.

${ }^{67}$ Above, n 27, cl 55.
} 
Collaboration and cooperation between different agencies depends upon the personalities of the individuals involved, the perceived benefit of any such collaboration and that the institutions themselves permit collaboration and cooperation. Whilst there is the potential that individuals can have conflicting opinions, the institutions and norms established by CIMS in New Zealand mean that outright stalemate or egotistic disputes are unlikely. Explicit legislative endorsement, in the empowering acts of emergency services, for inter-agency cooperation also exists. ${ }^{68}$

However, the Fire Service Act, s 32 states that the authority of persons in charge of a fire brigade must be recognised by all members of the Police, traffic officers and all other persons present at any fire or suspected fire or other emergency. ${ }^{69}$ On face value, the inclusion of 'or other emergency' to this section seems to conflict with CIMS procedures in that authority in emergency situations goes to whichever agency is best suited to deal with that incident. It also conflicts with academic commentary that in the majority of emergency incidents "police appeared to be in charge of operations throughout, partly because they were first on the scene and partly because no other person or group assumed responsibility.”70 This provision is not an accurate reflection of the current practice of CIMS and should be amended to better reflect the cooperative CIMS approach. The Fire Service Act 1975 is considered to be outdated, and in need of amendment to better empower and limit the Fire Service. ${ }^{71}$ Amendment of this section to better reflect current CIMS practices would clarify the relationship between the Fire Service and other emergency management actors.

\section{Obligations and Liabilities of the Private Sector}

New Zealand is a very disaster-prone country. Civil Defence aims for earlier declarations of emergency, thus allowing people to be at home rather than work. However, some emergencies, such as earthquakes, can strike at any time. It is therefore fundamentally important to the protection of New Zealand people and property that not only the public sector is prepared for these eventualities. The private sector must be included in civil defence emergency management. In the 1980s, this became a focus for Civil Defence,

\footnotetext{
68 Policing Act, s 10.

69 Section 32(1) (emphasis added).

${ }^{70}$ Lexa Hilliard “Local Government, Civil Defence and Emergency Planning: Heading for Disaster?” (1986) 49 The Modern Law Review 476 at 483.

${ }^{71}$ Above, n 34.
} 
committing to raise public awareness and the need for preparedness of private sector employees. ${ }^{72}$ Fast-forward 30 years, and Civil Defence is still seeking to get businesses on board. Resources are available to help create emergency management and business continuity plans. Various brochures for different stakeholders, under the marketing "It's Easy: Get prepared for an emergency” provide information for steps to be taken.

\section{A Obligations}

Despite this, there is not enough communication between emergency management actors and the private sector. This was evidenced during the Seddon earthquake, where it was unclear if actors, such as the university, had responsibilities or obligations to provide emergency management responses. There are three possible ways to remedy this issue.

\section{Legislated Obligations}

One solution is to legislate civil defence obligations for the private sector. The public sector is legally obligated to ensure they are able to operate following an emergency, even if this is in a reduced capacity. ${ }^{73}$ In practice, this means the creation of emergency management and business continuity plans. The private sector has no such civil defence obligations, with the exception of those businesses classified as lifeline utilities. Those that supply power, water, transport hubs and communication channels have the same statutory obligation as the public sector. ${ }^{74}$ The reason for this obligation is to ensure essential public goods are still available following an emergency.

While this reason is not as applicable to most private sector actors, an obligation to create emergency management plans can still be of benefit. Importantly, these allow businesses to understand the appropriate preparations for and responses to emergencies. Currently, the only private sector obligations relevant to emergency situations come from the Health and Safety in Employment Act 1992. Crucially, employers have a duty to take all practicable steps to "develop procedures for dealing with emergencies that may arise while employees are at work". ${ }^{75}$ There is no definition of emergency in this Act, making it unclear if this refers to all possible emergencies, or only those created in the workplace.

\footnotetext{
${ }^{72}$ Minister of Civil Defence with the Assistance of the Historical Branch: Department of Internal Affairs (MoCD) Civil Defence in New Zealand: A Short History (1990) at 25.

${ }^{73}$ Civil Defence Emergency Management Act, s 58.

${ }^{74}$ Section 60.

${ }^{75}$ Health and Safety in Employment Act 1992, s 6(e).
} 
Changing the wording of health and safety legislation to explicitly include the need to plan for civil defence emergencies would be prudent. People spend a large portion of the day at their place of work. Despite Civil Defence attempts to declare states of emergency before people become stranded at work, emergencies can happen at any time. There is a strong possibility that people will be at work when an emergency occurs. Employees often look to their employer as a source of authority, and this is likely to be the case in an emergency situation. Taking the university context as an example, students are likely to look to tutors and lecturers for guidance, even though Victoria University has no statutory authority for emergency management. ${ }^{76}$

Unlike public entities, the private sector should not be obligated to function postemergency; they should simply need to have established plans and procedures to cope in the immediate aftermath. This would include evacuation plans, contact details of staff, and potentially plans for welfare provision. Integrating civil defence into the health and safety legislation ensures that all businesses are under the same obligations. In addition, rather than placing the burden of enforcement upon Civil Defence, it can be incorporated into existing health and safety inspections. Explicitly including such a responsibility would clarify the position of employers, allowing them to effectively plan in order to mitigate harm to their employees and business. Employees would benefit from increased risk management, and clearer instructions on emergency procedures, as well as any welfare concerns. These private sector obligations could also help to reduce the pressure on Civil Defence, as workplaces would be better prepared to manage on their own steam following an emergency. Civil Defence would better able to focus upon mitigating the emergency and treating casualties. For all stakeholders, clarity around the obligations of the private sector would help ensure better readiness, more effective communication and responses prior to, and following, an emergency, which will hopefully mitigate potential damage.

There are negatives to such private sector obligations. Enforcement may be an issue, especially if it is down to Civil Defence personnel to review such plans. It could be difficult, especially for small businesses, to create practical and useful plans when most private actors have little knowledge of emergency management. Ensuring the quality of

${ }^{76}$ Kelburn IMT Emergency Response Plan (Victoria University of Wellington, September 2013) at 38. 
plans would overburden Civil Defence and detract from their other important work in increasing readiness across all sectors of New Zealand society. Incorporating enforcement into the existing role of health and safety inspectors could mitigate this. However, they are not trained to assess civil defence matters. In addition, it is still likely that each plan would be dependent on the specifics of the business, such as location, and therefore be hard to assess in the abstract.

Further, there is no guarantee that plans of various businesses would be consistent, with each other or with local and national plans. There would need to be coordination of these plans, as the contradictions could be deadly in an emergency. For instance, Victoria University's Emergency Response Plan details that in the event of an emergency at Pipitea Campus, staff and students should evacuate to Parliament grounds. ${ }^{77}$ Following the earthquakes in 2013, trolley-bus lines had fallen down across the road. These live lines meant it was unsafe to cross to Parliament grounds in this way. Staff and students were subsequently confused about where to assemble, and if it had been a larger earthquake, which caused a tsunami, there would have been no easy way to get to the assigned meeting place.

\section{Inclusion in Existing Infrastructure}

It could be advisable to further include the private sector in the existing civil defence infrastructure, such as within CDEM Groups. As can be seen, the private sector plays an important role in the preparation for dealing with an emergency. Including the private sector in creating CDEM Group plans enables more practical and effective implementation, as there has been input from the businesses and people who will be dealing with an emergency in their own workplaces. Excluding the private sector as a stakeholder in CDEM Groups weakens vital communication channels and relationships. Just as the relationship between emergency services is regularly maintained via CDEM Groups, so could the relationship with the private sector. Examples could include inclusion of a representative from the Chamber of Commerce, industry groupings or large employers such as the universities.

${ }^{77}$ Ibid at 19. 
However, it is unlikely that the inclusion of the private sector in CDEM would do much more than add a business perspective to CDEM Group Plans, and improve communication lines. The inclusion of city council members is adequate to provide this perspective, as elected representatives of the wider public. Further, including the private sector in CDEM Groups runs the risk that discussions around whether or not to declare an emergency would be overly influenced by motives around profitability, rather than public safety. Such inclusion of the private sector in CDEM Groups would therefore be undesirable.

\section{No Change}

The final option is to leave things as they are. As the saying goes, 'don't fix it if it isn't broken'. This approach assumes that the current health and safety legislation is interpreted as not requiring emergency management plans, meaning employers do not have any obligation to provide instructions or advice on what to do following an emergency. Actions taken during an emergency are then up to each individual, while still needing to comply with orders given by emergency management actors. These could include instructions by Police and Civil Defence personnel to evacuate areas ${ }^{78}$, and it would be an offence not to comply unless there were not "reasonable grounds for believing that in all the circumstances of the case [it is] necessary for the preservation of human life". ${ }^{79}$ Under this approach, it is up the individual to use common sense, and take ownership for their own readiness and safety regarding emergencies. According to Civil Defence, individuals are expected to take responsibility for their own welfare for at least 3-5 days. ${ }^{80}$ No further legislation is required under this approach. However, that also means that there is no guarantee either of increased clarification or of compliance with existing obligations.

Of these three options, the first best addresses the current issues with private sector actors and the civil defence regime. As many businesses and institutions already have emergency response plans, obligating plans would not create a burden. Victoria University of Wellington is one such institution. Its Emergency Response Plan acts in

\footnotetext{
${ }^{78}$ Civil Defence Emergency Management Act, s 86.

${ }^{79}$ Section 99.

${ }^{80}$ Above, n 11.
} 
coordination with the Business Continuity Plan and Risk Management Plan to create the university's internal rules regarding emergency hazards and responses. The Plan is being expanded, following a guideline from the Tertiary Education Commission in 2012, which is currently not yet ratified. ${ }^{81}$ The university's Emergency Response Plan comprehensively details the advised response for a variety of different emergency situations: flooding, severe weather, fire, earthquakes, acts of violence and pandemics. ${ }^{82}$ Although it is not a legal requirement to have a plan, those that exist must comply with CDEM Group Plans, as Victoria’s does. However, while staff should undertake the best efforts to help students, legislative obligations need to reflect that imposing liability for reasonable actions or omissions taken during emergencies could be unjust.

\section{B Liability}

With existing or potential future civil defence obligations for employers comes the question of liability. Currently, it is an offence for anyone to "intentionally [fail] to comply with a requirement in a civil defence emergency management plan."83

If the private sector is given similar obligations to the public sector, logic demands that they should face similar levels of liability. For the public sector, individuals empowered by the CDEM Act could be liable to judicial review as they have powers and make decisions under a statutory grant of power. ${ }^{84}$ In order to prevent liability, s 100 of the CDEM Act explicitly states: ${ }^{85}$

(1) Except as provided in sections 107 to $109^{86}$, there is no cause of action against the Crown, or a Civil Defence Emergency Management Group, or an officer or employee or member of any of them, or against any other person, to recover damages for any loss or damage that is due directly or indirectly to a state of emergency.

(2) Subsection (1) applies whether the loss or damage is caused by any person taking any action or failing to take any action, so long as the act or omission occurred in the exercise or performance of his or her functions, duties, or powers under this Act.

\footnotetext{
${ }^{81}$ Email from Rainsforth Dix (Associate Director Campus Operations) to Rebekah Gerry regarding VUW’s emergency management plans (31 July 2014).

82 Above, $n$ 76, at 8.

${ }^{83}$ Civil Defence Emergency Management Act, s 95.

${ }^{84}$ Judicature Amendment Act 1972, s 4.

${ }^{85}$ Section 110 (emphasis added).

${ }^{86}$ These sections relate to compensation for requisitioned property, loss suffered by Civil Defence staff and narrow exceptions.
} 
As shown by the added emphasis, this prevents a cause of action against any person, so long as it relates to functions, duties or powers under the CDEM Act. Except in the event of bad faith or gross negligence, this protects all those empowered by the CDEM Act. This would include private sector actors and individuals who were acting following authorisation from the Police or a CDEM Group. For example, if a member of the Police or CDEM Group considered it necessary to evacuate Victoria University, they could authorise university staff to carry out that evacuation. ${ }^{87}$ Presuming that Police and Civil Defence staff are acting legally, all instructions and authorisation given and then carried out by other persons would fall under s 100, and thus be excluded from liability.

The question is - are those taking action, not based upon the CDEM Act given the same protection? Sub-section (2) explicitly limits the exemption from liability to those acting under the authorisation of the CDEM Act. This appears to imply that those who take action without authorisation may find themselves liable, but should they be?

Victoria University's Emergency Response Plan gives some indication as to what obligations staff are under. It currently places an onus upon lecturers and tutors during a fire to evacuate their class to a pre-designated areas. ${ }^{88}$ There is not the same obligation following an earthquake. Instead staff are told to "encourage all those who are not assisting with tasks to go home". ${ }^{89}$ Is there, or should there be, liability if students are hurt in the process of complying with university instructions, which are not based on Civil Defence or Police advice? As mentioned above, Victoria University has no statutory power of emergency management. Although the Emergency Response Plan states that "individuals will need to make their own decisions regarding where they want to go, based on the conditions around them", the nature of the relationship, means many students will listen to whatever staff tell them. ${ }^{90}$ This means staff must be cautious in the advice and instructions they give out following an emergency. Further, warden staff members are explicitly expected to give instructions to students. Such responsibility is a

${ }^{87}$ Civil Defence Emergency Management Act, s 86.

${ }^{88}$ Above, $n 76$, at 9.

${ }^{89}$ Above, $\mathrm{n} 76$, at 19 .

${ }^{90}$ Ibid. 
huge burden to place on staff, who are not paid, trained or contractually obliged to give instructions following an emergency. Due to the nature of their relationship with students, it is inevitable that they must be the ones on the ground giving advice, or risk sheer panic. Therefore, university management should give staff clear and concise guidelines, and training to help understand this responsibility.

To prevent liability of university staff in these situations, legislative protection should be extended to cover all those who act reasonably, in the context of an emergency and with the information known, to prevent loss and damage. To hold individuals liable for actions taken in the panic of an emergency would be an injustice. Further, not protecting individuals may lead to situations such as those that have been seen in the United Kingdom. Two recent incidents there have highlighted the potential liability faced by individuals who are paralysed by fear of liability. In one scenario, a woman fell into a mineshaft. The extraction equipment regulations stated it was for emergency services crew only, and so her extraction was delayed and she subsequently died. ${ }^{91}$ Another scenario occurred when a man drowned in a three-foot lake. Emergency responders refused to go in due to health and safety reasons, as the water was more than ankle-deep. ${ }^{92}$ Not extending the protection to all individuals may create an atmosphere, in institutions and in the minds of the public, that preventing individual liability is more important than saving lives. This is not the desired outcome of civil defence or health and safety legislation. Thus, the legislative protection given to those with powers authorised by the CDEM Act should also be extended to all individuals whose action or inaction is reasonable given the emergency circumstances.

\section{Conclusion}

This paper has sought to clarify the CDEM Act and related legislation, particularly in the context of the role of the private sector. For the most part, emergency management in New Zealand works very well. Planning and guidelines, particularly around large-scale incidents, are done well. Communication between the key emergency response actors is strong, with CIMS ensuring that all know their appropriate roles and responsibilities.

\footnotetext{
91 “No prosecution over Alison Hume Ayrshire mineshaft death” BBC News (online ed, United Kingdom, 29 November 2013).

${ }^{92}$ Ben Quinn "Man drowned in shallow lake after firefighters 'not allowed' to rescue him” The Guardian (online ed, London, 22 February 2012).
} 
There are, however, issues with this regime. The definition of 'emergency' is inconsistent between acts, and perhaps requires a lower threshold to meet common understandings. It is uncertain what powers are available to emergency management actors without a formal declaration of emergency, and in practice, declarations of emergency are linked to the need for special emergency powers. However, the powers of some actors are unclear, due to outdated or non-existent legislation. This tie between states of emergency and special powers sometimes discourages declarations, if the everyday powers of other actors are deemed to be sufficient. As a result, there is opaque communication with the wider community and private sector. Further, the obligations and liabilities of the wider community and private sector are not clear.

Five recommendations are suggested to solve these issues. First, the definition of emergency in the CDEM Act should be lower, aligning with other emergency management legislation and layman understandings. Second, communication around declarations of states of emergencies should be clarified, with reasons given to the public for non-declarations. Third, legislative change is needed to confirm the CIMS practices that exist between emergency management actors, with particular reference to the Fire Service and Urban Search and Rescue. Fourth, civil defence obligations to create emergency management plans should be explicitly included in existing health and safety duties. This would be preferable to any inclusion of the private sector in existing civil defence infrastructure. Finally, the protection from liability granted to those authorised by the CDEM Act should be extended to all those who acted reasonably in the context of an emergency.

Adopting these recommendations would go a long way in clarifying the emergency management regime both for the actors within it and the private sector. Clarity and coordination can only be desirable, and one hopes that they will go far in preventing loss and damage in the next emergency situation in which New Zealand finds itself.

\section{Bibliography}

\section{A PRIMARY SOURCES}

\section{Legislation}

Civil Defence Emergency Management Act 2002. 
Defence Act 1990.

Fire Service Act 1975.

Health and Safety in Employment Act 1992.

Judicature Amendment Act 1972.

Policing Act 2008.

Resource Management Act 1991.

2 Statutory Instruments

National Civil Defence Emergency Management Plan Order 2005.

3 Papers and Reports

Minister of Civil Defence with the Assistance of the Historical Branch: Department of Internal Affairs (MoCD) Civil Defence in New Zealand: A Short History (1990).

Ministry of Civil Defence Director's Guidelines for the CDEM Sector (DGL13/12, March 2012).

Victoria University of Wellington Kelburn IMT Emergency Response Plan (v 2.5, September 2013).

Wellington Region Civil Defence Emergency Management Group Plan 2013-2018 (1 July 2013).

\section{B SECONDARY SOURCES}

1 Academic Articles

Lexa Hilliard "Local Government, Civil Defence and Emergency Planning: Heading for Disaster?” (1986) 49 The Modern Law Review 476 at 483.

Matthew McKillop "Emergency Powers of the New Zealand Government: Sources, Limitations, and the Canterbury Earthquake” (Otago University Honours Dissertation, October 2010).

2 Newspaper Articles

“No prosecution over Alison Hume Ayrshire mineshaft death” BBC News (online ed, United Kingdom, 29 November 2013).

"Work to begin to demolish lift shaft following Wellington quake" One News (online ed, New Zealand, 16 August 2013). 
Ben Quinn "Man drowned in shallow lake after firefighters 'not allowed' to rescue him” The Guardian (online ed, London, 22 February 2012).

Jo Moir "Lecturers to cut law students some slack" The Dominion Post (online ed, Wellington, 24 July 2013).

Rebecca Quilliam “Wellington earthquake: 35 buildings damaged in CBD” The New Zealand Herald (online ed, Auckland, 2 July 2013).

\section{Press Releases}

Beehive "Ministerial List for Announcement” (press release, 22 January 2013).

Beehive “State of national emergency expires” (press release, 2 May 2011).

\section{Interviews}

Interview with Bruce Pepperell, Wellington Region Emergency Management Regional Manager (Rebekah Gerry, 31 July 2014).

Interview with Stu Rooney, National Operations Officer of NZ Fire Service (Rebekah Gerry, 1 August 2014).

\section{Website}

“New Zealand Fire Service USAR team helping out in Wellington” (22 July 2013) New Zealand Fire Service <www.fire.org.nz>

\section{Email}

Email from Rainsforth Dix (Associate Director Campus Operations) to Rebekah Gerry regarding VUW’s emergency management plans (31 July 2014).

\section{Word Count}

The text of this paper (excluding cover page, abstract, table of contents, non-substantive footnotes and bibliography) comprises 7970 words. 